\title{
Images of this Present Life in the Rhetoric of John Chrysostom
}

\author{
Raymond Laird \\ Australian Catholic University, Brisbane, Australia \\ rlairdlap@exemail.com.au
}

\section{Summary}

In determining the attitude of John Chrysostom to life in this present age, examination is made of the various images that this great rhetorician of the Church used in his homilies and writings. It could be said that the power of his oratory reaches its apex in the images frequently employed throughout the corpus of his extant works. This is no less the case in his references to our earthly lives. Inevitably linked with his pastoral concerns about human passions that endanger spiritual growth, the canvas for the main part is filled with images of disdain for and warning of worldly values, and of encouragement to focus on the heavenly riches.

\section{Keywords}

images used by John Chrysostom - John Chrysostom's rhetoric

John Chrysostom's worldview is neatly summed up in his comments on verse 1 of Psalm 120:

...if we are not possessed by the love of the heavenly things and the desire of the Jerusalem above, but ever remain attached to the present life, wallowing in the mire of earthly concerns, we shall never succeed in taking possession of our homeland. ${ }^{1}$

1 St John Chrysostom, Commentary on the Psalms, In Psalmos 120, tr. R.C. Hill, vol. 2, Brookline, MA, 1998, p. 133. 
There is no doubt that he understood Christians to be strangers and pilgrims on the earth, that their homeland is the heavenly Jerusalem above, and that gaining it is the prime concern of life. Thus, to his mind, earthly concerns needed to be treated, not as unimportant, but as secondary. In his eyes the great danger was to allow, or to choose to make, those earthly concerns become the core focus of life, a condition Chrysostom vividly describes in his image of a pig wallowing in the mire, delighting in the mud that gives it great pleasure. ${ }^{2}$ This indicates that he was convinced that a mindset of detachment is the order of the day for the Christian pilgrim. ${ }^{3}$ Chrysostom's picture of earthly life appears to be gloomy, with dangers lurking all around, a world filled with demons using all sorts of deceits to entrap the unwary, especially through the things that many deem to be the pleasures of life.

The choice appears sharp: be possessed by the love of the heavenly in order to possess the promised homeland, or be obsessed by the earthly and never possess the heavenly Jerusalem. Yet, let it not be thought that Chrysostom was entirely negative about our present life. A comment on verses 5 and 6 of the same Psalm makes clear that he appreciated this life as a God created gift, one to be enjoyed: "In saying this I do not malign the present life - perish the thought: it is God's work." ${ }^{4}$ He was well aware that life itself is somewhat greyer than either white or black but, as a shepherd of the Christian flock, his pastoral concern for their protection and growth constrained him to make effective use of his rhetorical skills. One was hyperbole, with the result that many of the images employed by him are blatantly larger-than-life in order to make good his point. It could be said that the power of his oratory reaches its apex in the images frequently employed throughout the corpus of his extant works. This is no less the case in his references to our earthly lives. One must allow for the fact that he was a trained and highly skilled rhetorician. ${ }^{5}$ This must be recognised

2 Pigs, lacking sweat glands, seek relief from heat by wallowing in the mud when the temperature rises above $22^{\circ} \mathrm{C}$. Chrysostom probably would not have known this fact, but for informed modern readers the metaphor is no less significant, probably more so, but in reverse, because for the pig it is a matter of life or death. Life or death was indeed the choice Chrysostom had in mind.

3 This Psalm belongs to the group known as the Songs of Degrees, or the Songs of Steps, or the Songs of the Ascents, often called the Pilgrim Psalms on the premise that they were sung on the way to the Temple in Jerusalem for the great festivals. J.H. Eaton, Psalms. Introduction and Commentary, London, 1967, p. 279.

4 John Chrysostom, Commentary on the Psalms, In Psalmos 121.5-6, tr. Hill, p. 137.

5 See among the many who laud the rhetorical skill of John Chrysostom, M.M. Mitchell, The Heavenly Trumpet:John Chrysostom and the Art of Pauline Interpretation, Louisville, KY, 2002, pp. 22-28; P. Allen. W. Meyer, John Chrysostom (Early Christian Fathers), London - New 
in approaching the theme of this present analysis where hyperbole abounds. As noted above, Chrysostom himself warns his congregation not to accept an extreme which he uses for emphasis, but to accept the point he is attempting to make.

Another caution for readers is found in Chrysostom's experience prior to becoming a preacher in the Church. The years he spent as a monk marked the time when he became deeply imbued with ascetism. Elizabeth Clark, in her Reading and Renunciation, has argued that this experience affected his exegetical approach with regard to participation in certain social practices. ${ }^{6}$ On the other hand, this is by no means the total picture, as Chrysostom's education in the Greek paideia had already presented him with the critical elements of a life philosophy: a worthy goal, a pathway towards it, and the final gateway to this desired objective. From the very source that he came to despise for their distortions, that is the Greek philosophers, especially Plato, he had learned that the goal is wisdom; the pathway is virtue and denial of our passions; and as the desires of the body were viewed as the great barrier to virtue, then the final step was seen by Greek Philosophers to be the transition by death to a bodiless existence. ${ }^{7}$ Thus, although Chrysostom turned from what he perceived to be the deficiencies and falsehoods of the pagan philosophers, ${ }^{8}$ his mindset was

York, 2007, p. 27; J.L. Maxwell Christianization and Communication in Late Antiquity: John Chrysostom and his Congregation in Antioch, Cambridge, NY, 2006, passim, is commendable for its contextual placing of the role of Chrysostom's preaching; John Chrysostom, Old Testament Homilies, vol. 3: Homilies on the Obscurities of the Old Testament and Homilies on the Psalms, tr. R.C. Hill, Brookline, MA, 2003, p. 140, endn. 39, makes the comment that "One has only to compare Chrysostom's commentary on a Psalm (in his pulpit) with Diodore's, Theodore's, and Theodoret's (at their desks) to see the impact of the homilist's use of his considerable rhetorical skills that won him his sobriquet."

6 E.A. Clark, Reading and Renunciation:Asceticism and Scripture in Early Christianity, Princeton, NJ, 1999, p. 13.

7 B. Jowett, Plato, Phaedo 63-68, in: The Dialogues of Plato, ed, R. M Hutchins, J. Alder (Great Books of the Western World, 7), Chicago, IL - London - Toronto - Geneva, 1952, pp. 222-225. See also for other Platonic influences upon Chrysostom, C. Bozinis, "Two platonic images in the rhetoric of John Chrysostom: The wings of love, and the charioteer of the soul," Studia Patristica, 41 (2006), pp. 433-438.

8 John Chrysostom, In 1 Cor. hom. 7.47-64, in PG 61, col. 60.36-7: "The sceptre of knowledge was

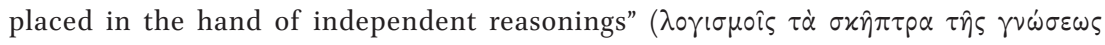
$\varepsilon \gamma \chi \varepsilon i p i \sigma \alpha \nu \tau \varepsilon \varsigma)$, rather than in the hand of the Holy Spirit; see R. Laird, Mindset, Moral Choice and Sin in the Anthropology of John Chrysostom (Early Christian Studies, 15), Strathfield, 2012, pp. 243-251, for a discussion on the fall of reason according to Chrysostom. Further references to Migne texts of John Chrysostom will read, John Chrys., In 1 Cor. hom. 7, PG 61, col. 6o, with homily details changed for appropriate biblical book. 
already shaped towards a Christian equivalent of a path to true wisdom, that of a monastic vocation in one or other of its forms. ${ }^{9}$ It should be no surprise then that he should choose that path with its space to fight his personal demons, to absorb the Scriptures, and to attend to the development of personal and communal godliness. It could be said that this experience was a perfect preparation for his pastoral ministry. Its impact was appropriate for the training of his congregations' mindsets in discipline toward a Christian philosophia. ${ }^{10}$ Both sources, Pagan philosophers and Christian monasticism, led to his strong preaching against "the evils paraded in the city," namely the theatre, the circus, and the chariot races. ${ }^{11} \mathrm{He}$ understood that the world was driven by Satan, but in his homilies his major thrust was aimed at the world of human decadence that in his opinion, as was taught by his sources, was firmly lodged in human spirits, or mindsets. He taught that Baptism would effect an initial renovation of the mindset $\left(\gamma \nu \omega^{\prime} \mu \eta\right),{ }^{12}$ but unless the mindset was subsequently properly shaped by teaching, warning, and admonition, the sheep under his care were in danger of falling away or being overcome by the devil. Hence, his vivid and florid images were used to match the height of the danger he discerned.

There are a number of images used by Chrysostom that appear to be expressing a totally negative view of this present life. One of them is in homily 14 on Matthew where he asserts that this present life is a prison, ${ }^{13}$ an image that was probably a legacy of the Platonic thought he had learned and had come to despise in which the human body in its persistent loves and lusts is observed as

Recent discussions of Chrysostom's experience of the monastic life have leant towards a city-based expression. See W. Mayer, "Monasticism at Antioch and Constantinople in the Late Fourth Century," in: Prayer and Spirituality in the Early Church, ed. P. Allen R. Canning L. Cross, vol. 1, Brisbane, 1998, pp. 275-288.

A.-M. Malingrey, «Philosophia »: Étude d'un groupe de mots dans la littérature grecque des Présocratiques au IV siècle après J.C. (Études et Commentaires 40), Paris, 1961, pp. 263288, provides a perceptive survey of Chrysostom's usage of Christian $\varphi\left(\lambda \circ \sigma \circ \varphi \varphi^{\alpha} \alpha\right.$, including a definition at 268: "la foi chrétienne authentiquement vécue au milieu du monde" ("the Christian life lived authentically in the world").

11 B. Leyerle, Theatrical Shows and Ascetic Lives, Berkley, CA, 2001, pp. 13-41; P.L. Brown, "Sexuality and the City: John Chrysostom," in: The Body and Society: Men, Women, and Sexual Renunciation in Early Christianity, ed. P.L. Brown, Colombia, 1988, pp. 305-322; B.H. Vandenberghe, "Saint Jean Chrysostome et les spectacles," Zeitschrift fur Religions- und Geistesgeschichte, 7 (1955), ss. 34-36; See C. Jacob, Das Geistige Theater: Ästhetik und Moral bei Johannes Chrysostomus, Münster, 2011, passim, for a cogent analysis of Chrysostom's approach to the pagan theatre and his formula for an alternative spiritual theatre. For a comprehensive treatment of mindset ( $\gamma v \dot{\omega} \mu \eta)$ in Chrysostom's usage, see Laird Mindset, Moral Choice and Sin, passim.

13 John Chrys., In Matthew, hom. 14, PG 57, col. 222.20-21. 
the ultimate hindrance to the philosophers in their pursuit of wisdom. They thought that the body was the prison of the soul until its release in death. ${ }^{14}$ Chrysostom does not stop with the body; indeed he exonerates it from ultimate blame, likening it in one of his homilies to a suit of armour as being neutral. ${ }^{15}$ He would have his congregation examine their souls, but even then not the soul in its essence (ovं'i $\alpha$ ), which he holds that as the creation of God is removed from accusation. ${ }^{16}$ This amounts to a rejection of much of his philosophical roots. Rather he referred his congregation to a faculty of the soul, the mindset ( $\gamma(\omega) \mu \eta)$, which Chrysostom asserts had become the hegemon of the soul as a result of the Fall. This domination, he taught, includes the power of choice for good or evil, meaning then that the mindset controls the passions. ${ }^{17}$ For those who yield to the passions, especially the pursuit of wealth and luxury, Chrysostom pictures life as the worst of prisons where they are bound in chains. ${ }^{18}$ All is squalid, filthy, and crawling with vermin. ${ }^{19}$ He presents this as not something to be chosen, for not only has the prime human attribute of freedom been misused and lost, but the captivity image is intensified to the extreme so that a governing focus on the affairs of this life is depicted as a hopeless outlook with a horrible outcome.

Chrysostom, also in his Matthew homilies, applies the metaphor of a broken cistern to those "labouring for this present life." ${ }^{20}$ In this image he expresses the futility of the present life. The water supply so vital to existence has leaked away. There is no return for the energy, skill, and the time expended in the building of the cistern. Ultimately, nothing comes of it. The metaphor is then changed to press home the point - stoking a fire by combing wool into it; this is useless because wool is fire-resistant. ${ }^{21}$ It is a completely pointless act. The rhetor par excellence, in order to convince, adds metaphors from the world of sports so as to reinforce his contention: "beating the air"22 and "running in

Plato, Phaedrus, 250, GBww, 7, p. 126, where Socrates remarks about being "enshrined in that living tomb which we carry about now that we are imprisoned in the body, like an oyster in his shell."

15 John Chrys., In Rom. hom. 11, PG 6o, col. 487.7-9.

16 John Chrys., In Rom. hom. 13, PG 6o, col. 510.19-20.

17 John Chrys., In Rom. hom. 13, PG 6o, col. 518.24-27.

18 John Chrys., In Matt. hom. 14, PG 57, col. 222.21-3. See Plato, Phaedo, 67, GBww, p. 225, where Socrates looks forward to "the release of the soul from the chains of the body."

19 John Chrys., In Matt. hom. 14, PG 57, col. 222.43-45.

20 John Chrys., In Matt. hom. 76, PG 58, col. 701.45-47.

21 John Chrys., In Matt. hom. 76, PG 58, col. 701.47.

22 John Chrys., In Matt. hom. 76, PG 58, col. 701. 48. 
vain."23 These metaphors, as with Paul (1 Cor 9:26), clearly convey the futility intended by Chrysostom. He endeavoured to turn his audience from exerting their energy in living solely for this present life. He makes sure that his point has not been lost by ending with the exclamation that such a life-focus is a "vanity of vanities." ${ }^{4}$

On the same theme, Chrysostom, in a homily on 1 Timothy represents the present life by bringing together two images, one the scene from a theatre stage, and the other a dream. ${ }^{25}$ Both are transient and unreal. Soon the scene is over and another takes it place. Dreams too are fleeting, also empty, without substance, usually distorted, confusing, often frightening, and mostly forgotten on awaking, thus disappearing unremembered. Earthly life on the scale of eternal reality is in essence unreal. Thus, when instructing neophytes in preparing them for baptism, he tells them to ensure that their focus is true from the beginning: concentrated on the things of heaven and not gaping after the goods of this world such as the glory of this life, luxury, and the honours that men can confer. ${ }^{26}$ They should treat mundane affairs as dreams and shadows. ${ }^{27}$ This theme is also taken up in his homily on Psalm 112 where he again presents them as "futility and shadow and things of no substance."28 In this category he enumerates wealth, influence, bodily charm, and an affluent environment, likening these to "falling leaves, passing shadows and fleeting dreams."29 In this regard, of particular concern to Chrysostom were those who had given themselves over to the passion for power. He presents that choice as dust and water, ${ }^{30}$ thus conveying the futility of that course. The images suggest a lack of permanence or substance. Dust is easily swept or blown away. He leaves no doubt as to his meaning by intensifying the metaphor with the image of the dust being stirred up and the water streaming away. ${ }^{31}$ Such are those who grasp after dominance. In this figure a warning is given of the hidden dangers that exist for those who choose the path of the pursuit of power: in the process the dust becomes air-polluting and eyes-blinding. ${ }^{32}$ As a good shepherd Chrysostom,

\footnotetext{
23 John Chrys., In Matt. hom. 76, PG 58, col. 701. 48.

24 John Chrys., In Matt. hom. 76, $P G$ 58, col. 701.51.

25 John Chrys., In 1 Timothy hom. 15, PG 62, col. 584. 22-25.

26 John Chrysostom, Baptismal Instructions, ed. P.W. Harkins (Ancient Christian Writers, 31), Westminster, MD, 1963, p. 124.

27 John Chrys., Baptismal, ed. Harkins, pp. 109-110.

28 John Chrys., In Psalmos 112, tr. Hill, от Homilies, vol. 2, p. 54.

29 John Chrys., In Psalmos 112, tr. Hill, от Homilies, vol. 2, p. 54.

30 John Chrys., In Colossians hom. 7, PG 62, col. 346.51-55.

$3^{1} \quad$ John Chrys., In Colossians hom. 7, PG 62, col. 347.8-13.

32 John Chrys., In Colossians hom. 7, PG 62, col. 347.17-21.
} 
by deterring any of his flock from taking that path, seeks to shield them from those awful consequences of being choked of spiritual life and blinded to the truth of the word of God.

Chrysostom throws a very interesting perspective on our present life when he calls it "a nest cemented together with sticks and mire,"33 not an inviting scene for humans, but one that has magnetic force upon its natural residents, the swallow. The problem is intensified with an addition to the metaphor of the presence of spoiled nestlings that instead of moving out as they grow to forage for themselves choose to remain permanently in the nest, thus becoming weaker and weaker from lack of food. ${ }^{34}$ There appears to be no incentive to move and soar into the real life for which the birds were created and fashioned. Chrysostom applies this scene to those people with self-centered passions, calling them lovers of the body, at ease in this life in their mansions and palaces living in their narcissistic luxury. Not only do such persons disregard not only the end of their purpose-built residences, their bodies, but also their own destiny for which they were created. In the end the winter of divine judgement will come upon them when they will find that they are too weak to fly, and thus shall perish like the swallows in their falling nests. In these vivid images Chrysostom endeavours to call his people to concentrate their focus on their beautiful heavenly homeland.

Not all of Chrysostom's metaphors belong to the category of the vanity of vanities. Some belong to the species that could be termed the variability of life. For example, he likens life to the Seasons - variable, moving from one aspect to another in a perpetual shift. ${ }^{35}$ Life also moves in such a fashion, from health to sickness, from pleasure to pain, as night is replaced by day. There is no static state in life for its duration. In his homily on Psalm 49:16 he likens human affairs to a similar metaphor of flowing rivers: "one time coming into view flowing by, at another time checked and changing direction."36 There is no certainty in the ebb and flow of life's fortunes, none that is except death; hence his labours to have his people adopt the focus on the surer heavenly hope. Chrysostom pictures life to one group of his neophytes as a wheel, constantly turning, at one moment down, at another up, not in smooth transitions but in sudden changes that disrupt the rhythm and progress, and may be a portent of

John Chrys., In Colossians hom. 2, PG 62, col. 314-315. From personal observance this author has watched swallows building their nests and gathering mud for them from the shallow puddles left after rain. Chrysostom was an acute observer of nature.

35 John Chrys., In Matt. hom. 53, PG 58, col. 530.

36 John Chrys., In Psalmos 49.16, ed. Hill, от Homilies, vol. 3, p. 90. 
disaster. ${ }^{37}$ This may seem more balanced a view, more realistic, true to life, but nonetheless it emphasises the uncertainty of life, a call in itself to adjust one's focus to that which is above. Chrysostom makes use of Paul's shipwreck in one of his homilies on Acts to image life as a voyage on a ship on the sea of life. ${ }^{38}$ This is not his main thought in his exegesis, but he does take the opportunity to slip it in. The ship is at the mercy of the sea with its changes from dead calm to threatening winds and waves in mere moments of time. The ship may seem safe but is always vulnerable, especially with the limitations of the materials and possible construction techniques available in the fourth century. In his homily on Psalm 120, again we find the ship and seas metaphor with scenes of "stormy straits, tossed by constant waves, storms and shipwrecks." ${ }^{39} \mathrm{He}$ avers that the substance of earthly life, as exemplified by sea and ship, cannot be totally trusted. Together the images shout for dependence upon the far greater security that Chrysostom proclaimed in Christ. As he says in his comment on Psalm 110 he wanted his people to be "unencumbered by any concern for the present life." 40 He saw his ministry as "giving them wings and making them tougher than steel,"41 thereby on one hand preparing them for heaven, and on the other equipping them to handle the exigencies of life.

Once again, Chrysostom qualifies his vivid metaphors by revealing his purpose in using such extreme images: "I am only stirring you to love the future."42 For him it is a matter of the primary focus of life. Therefore he uses the metaphor of sojourners to explain the mindset ( $\gamma v \dot{\omega} \omega \eta)$ required of his people to set them aright. They should live always like strangers passing through, of travellers on the road, ignoring present griefs and successes. ${ }^{43}$ The need is for de-

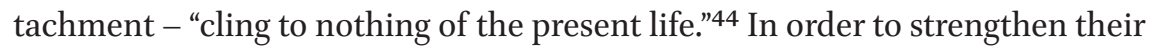
resolve, at times he points to the Tombs of martyrs that teach us to treat this present life with contempt, a better, more powerful image, he asserts, than his own preaching. ${ }^{45} \mathrm{He}$ would never let his congregations forget the inconstant nature of the things of earthly life so that they would not become infatuated with their glory and power. ${ }^{46}$

\footnotetext{
37 John Chrys., Baptismal, ed. Harkins, p. 125.

38 John Chrys., In Acts hom. 53, PG 6o, col. 318-319.

39 John Chrys., In Psalmos 120.5, от Homilies vol. 2, 135.

40 John Chrys., In Psalmos 110, ed. Hill, от Homilies, vol. 1, p. 31.

41 John Chrys., Baptismal, ed. Harkins, pp. 87-88.

42 John Chrys., In Psalmos 120, ed. Hill, от Homilies, vol. 2, p. 137.

43 John Chrys., In Psalmos 120, ed. Hill, ot Homilies, vol. 2, p. 137.

44 John Chrys., In Psalmos 120, ed. Hill, от Homilies, vol. 2, p. 137.

45 John Chrys., Baptismal, ed. Harkins, p. 104.

46 John Chrys., In John hom. 22, PG 59, col. 219.
} 
This counsel is strong medicine, but Chrysostom did not hesitate to prescribe it. His homilies on Genesis commence with his description of the church as a "medical clinic of the Spirit" 47 where they could receive suitable medicines for their souls. Also, both rhetorician and congregation knew that he was stretching the picture with his metaphors to highlight the gravity of the choices to be made. Nevertheless, he was not one to mince things, neither in diagnosis of the ills of the soul nor in the prescriptions that he dispensed as a cure. The remedies he advocated were no innovations, but those that had been tried and tested in the church from the days of the Apostles. Hence, with the catechumens he pointed to his beloved Paul. How could his people disdain the things of this present life? How could they focus persistently on the Jerusalem that is above? His answer: a positive response to the word preached would open them to the grace of the Spirit. The result would then be as Chrysostom described the experience of the Apostle Paul:

Did you see how the grace of the Spirit transformed his soul, and how it turned around his mindset ( $\alpha \dot{v} \theta \tau \circ \hat{v} \tau \dot{\eta} \nu ~ \gamma \nu \omega \dot{\mu} \mu \eta \nu \mu \varepsilon \tau \dot{\varepsilon} \beta \alpha \lambda \varepsilon$ ), how just like a fire falling into thornbushes, so the Grace of the Spirit came into and destroyed the thornbushes of his sins, and made him harder than the hardest metal. ${ }^{48}$

In Chrysostom's corpus it is this transformation of the mindset that is critical. In the issue of the focus of life, the many images that he employs to picture our present life lead to the distinctive mindset of the Christian pilgrims: one that is highly focused on future bliss, and that leaves no room for passivity. As our present life is fleeting, and impermanent, according to Chrysostom the mindset that God looks for, and which the Spirit of God would develop in us is defined by the qualities and epithets that Chrysostom uses with mindset ( $\gamma v \omega \dot{\omega} \mu \eta$ ). These include zeal, ardour, noble-minded, boiling/red-hot, craving, contempt, disdain for the present world's things, faith, courage, patience, and undaunted.

47 John Chrys., In Gen. hom. 1, PG 53, col. 22.9-12.

48 John Chrys., Baptismal, ed. Harkins, p. 87-88. The Greek text is from Jean Chrysostom. Huit catéchèses baptismales inédites, éd. P.A. Wenger (sc, 50), Paris, 1957, translation mine. 